\title{
Acquisition of Estonian - Early Words
}

(2012)

\author{
Tiiu Salasoo \\ Estonian Learning Materials, Sydney, Australia \\ salasoo@ihug.com.au
}

In natural language learning, children pick up spoken sounds from their surroundings, attach meanings to the various sound combinations and begin to operate these combinations in ways that enable progressively more and more complex communication. This most important achievement occurs effortlessly in children. This paper covers a small part of an ongoing project concerned with investigating how Estonian language is learnt naturally.

The developing speech of three small boys living in different linguistic environments, two in Australia and one in Estonia, has been observed and recorded over several years, when they were between the ages of 1,5 and 3 years. The parents of one Australian boy chose to raise him as a bilingual, with his mother using Estonian and his father English. Both parents of the other boy in Australia spoke Estonian, even though his mother had learnt it herself only recently, and there was an older half-sister in the household who communicated mainly in English. Thus, both boys in Australia had some exposure to English. The third boy in Estonia lived entirely in Estonian surroundings, and could be regarded thus as a control. None of the boys attended any child care establishments, so home influence was predominant.

The observed and recorded speech of the boys has been analysed at word level, in terms of the lexical and grammatical meaning of each word in context of a particular discourse, as well as its acquisition status.

Morphological and syntactic development of the boys' speech has been described previously (e.g., Salasoo 1996, 1998a, 1998b, 2001, 2002a). The major parts of speech -- the verbs, nouns, adjectives and adverbs -- used by the boys have been looked at and reported on, lately concentrating on the semantic aspect of their utterings (Salasoo 2002b, 2003, 2010a, 2010b).

A particularly prominent, but puzzling group of words in the boys' early vocabularies, which seemed to need further attention, were onomatopoetic words. It was decided to investigate their appearance and role, questioning whether onomatopoetic words could be somewhat easier to acquire than other types of words. 


\section{Onomatopoeia}

The term onomatopoeia has its origin in Greek, meaning 'word-making'. Onomatopoeic or onomatopoetic words mimic the sounds an object makes, and as such these words imitate, echo, or suggest the object or its associated action they are describing. As a simple example of onomatopoeia we can quote the English word 'clap', which in Estonian is plaks -- about the meaning of which no one can remain in doubt. According to Stefan Chiarantano (2006), in such words their sound represents the meaning of the word.

Onomatopoeia has not been investigated very much. However, it seems to occur in most languages, and Wai Chuen Thomas Tsoi and Chung Hoi Wai Clara (2004) claim that it occurs in all languages of the world.

In their study they chose 30 sounds grouped as:

1. Calls of animals

2. Sounds of nature

3. Sounds made by humans

4. Miscellaneous sounds

They compared onomatopes in twelve different languages: the Sino-Tibetan Cantonese and Mandarin, the Indo-European Italian, Spanish, German, English and Lithuanian, the Altaic Turkish, the Niger-Congo Swahili, the independent Korean and Japanese, and the Finno-Ugric Finnish. They found that in many of these languages the same phonemes are utilized as onomatopes conveying the same meaning, as shown in Table 1.

There are also other onomatopes that are not similar in all the languages, being modified by the characteristics of a particular language, by its phonological system either in hearing or, more likely, in reproduction, or its syllabic structure. For instance, some Asian languages lack the voiced fricative [z] to express the buzzing of bees and the nasal consonants [n] and [y] are used instead, nor do these languages allow double consonants in their syllables, with a vowel inserted between two similar consonants.

Assaneo, Nichols and Trevisan (2011) reported a comparison of the actual sounds made by objects or actions with the anatomical features of the vocal imitation used, and they felt it opened a new venue for a quantitative study of word formation.

Many onomatopes related to human activities, such as eating, drinking, spitting, etc., seem to show a connection between the kinesthetic functions and the meaning of the word, e.g., to produce [am] to signify eating, the mouth is opened fully to produce [a] and closed to produce the bilabial nasal [m], thus imitating eating itself (Tsoi and Chung 2004). 
Table 1: Characteristic phonemes of some common onomatopes (from Tsoi and Chung 2004)

\begin{tabular}{|l|l|}
\hline \multicolumn{1}{|c|}{ Sounds } & \multicolumn{1}{|c|}{ Characteristic phonemes } \\
\hline blowing wind & {$[\mathrm{u}]$} \\
\hline dripping water & {$[\mathrm{t}, \mathrm{d}]$} \\
\hline laughing & {$[\mathrm{h}]$} \\
\hline crying & {$[\mathrm{w}]+[\mathrm{a}]$} \\
\hline murmuring & {$[\mathrm{m}]$} \\
\hline speaking quickly & {$[\mathrm{p}, \mathrm{b}]+[\mathrm{l}]+[\mathrm{a}]$} \\
\hline eating & {$[\mathrm{a}]+[\mathrm{m}]$} \\
\hline drinking & {$[\mathrm{k}, \mathrm{g}](+[\mathrm{l}])+[\mathrm{u}]$} \\
\hline glass breaking & {$[\mathrm{p}] /[\mathrm{n}]$} \\
\hline ringing & {$[\mathrm{t}, \mathrm{d}] /[\mathrm{r}]+[\mathrm{i}] /[\mathrm{a}] /[\mathrm{o}]+[\mathrm{y}] /[\mathrm{n}]$} \\
\hline car beeping & {$[\mathrm{p}, \mathrm{b}]$} \\
\hline explosion & {$[\mathrm{p}, \mathrm{b}]+[\mathrm{a}] /[\mathrm{u}]+[\mathrm{y}] /[\mathrm{n}] /[\mathrm{m}]$} \\
\hline
\end{tabular}

Because of the universality of onomatopoeia, some linguists believe onomatopes were the first words spoken by humans when language evolved (Tsoi and Chung 2004). Imitation of natural sounds would have been easily understood and related to their source objects (certain animals, natural occurrences), as well as the actions of these objects. Over time these primitive sounds have developed into the onomatopes used today, which include some words we may not usually associate with their sources.

\section{Onomatopoeia in Estonian}

Estonian is very rich in onomatopoeia, with $20 \%$ of its words being onomatopoetic, according to Rätsep (1983). The lexicographer Enn Veldi has made an extensive study of onomatopoeia, describing it as "a phonosemantic subsystem modelling extralinguistic acoustic phenomena by means of the phonological structure of words in a given language" (1987). On such basis he has classified an inventory of 735 Estonian onomatopoetic words into 18 types, with 20 patterns, and has found that $39 \%$ of the inventory fit into two types: 
- Type 1 - The Instants, with 161 onomatopes, e.g.

TIKK-TAKK ('tick-tack' of a clock); KLÕOP (a light clicking sound, like closing a purse); KLUKSuma (like water flowing unevenly out of an opening, esp. the throat); SIDistama (to make a succession of short rapid sounds, like a bird), and

- Type 10 - The Tonal Postpulse Instants-Continuants, with 126 onomatopes in two subgroups, e.g.

- Subtype A - short, like TÜMPSuma (to make repeated dull sounds when striking with a heavy blunt object); PONTSatama (sound made by the falling of a soft heavy object); KOLKSuma (making repeated loud unpleasant sharp sounds, like metal striking upon metal); and

- Subtype B - prolonged, e.g., PLÕNNima (to play a stringed instrument without skill or care); PIMM-PAMM slow and repeated deep resonant sounds of a large bell; KILL-KÕLL (clear resonant sounds of small bells; TILL (a prolonged high-pitched sound, like a cash register).

Another $40.8 \%$ are made up of the following types:

- Type 5 - The Quasi-Instant Frequentatives, with 88 onomatopes, e.g., $(P) R A K S u m a$ (making sudden explosive sounds of ice or burning logs); KRAKSti (sudden sharp explosive sound as in braking); PLARTSti (sound of a body falling into water); SIRTSuma (making short sharp sounds, like birds or insects);

- Type 2 - The Tonal Continuants, with 76 onomatopes, e.g., PIIP-PIIP (beepbeep, the high-pitched tone of a motor horn or telephone); TUUT-TUUT (toot-toot, the low- pitched sounds of a horn); SIITSuma (to cheep like young birds);

- Type 3 - The Pure Noise Continuants, with 69 onomatopes, e.g., SISisema (to give a high-pitched prolonged sibilant sound, hiss; SOSistama (to whisper); LÕHisema (to make the sound of tempestuous flames; SIUH (the sound of cutting through the air, swish); KAHisema (to whisper gently through the leaves like the wind, to swish like taffeta;

- Type 6 - The Pure Frequentatives with 67 onomatopes, e.g., URisema (to make deep rough throaty sound like a dog, to growl; TIRisema (to make a high-pitched continuous vibrating sound like an alarm clock, to ring; PÕRisema (to make a deep continuous vibrating sound by a succession of quick strokes like an engine; SIRistama (to sing in a trilling manner like a bird, to chirr like a grasshopper; K̈̈Risema (to make a tearing sound).

The remaining $20 \%$ are scattered among the remaining types. 


\section{Onomatopoeia Among Observed Children Acquiring Estonian}

When classifying the words in the early utterances of the observed boys, sometimes it was quite difficult to decide whether a particular word indicated an object, and was thus a noun, or some action, and was thus a verb, or whether it was even meant to qualify nouns or verbs and was thus an adjectives or an adverb. Such units often seemed to imitate sounds made by certain objects, being onomatopes, or consisted of vigorous brief utterances, being exclamations.

A difficulty also occurred when trying to draw a clear distinction between exclamations, onomatopes and so-called baby-talk expressions. Nevertheless, an attempt was made, by examining such expressions in context. An utterance was regarded as being an exclamation when it was spontaneously uttered in response to some stimulus, e.g., ai! in response to pain, whereas the imitative utterances attempting to describe something were classified as onomatopes. Often the result was not clear-cut, e.g., ai (and versions of it) was at times a straight-out response to something painful, and at other times it was used to indicate that someone was in pain. Table 2 presents an attempt to separate these types of expressions.

Sometimes a particular concept was expressed synonymously by several differing words even during the same observation, but a change in terms occurred mostly over a certain period of time.

Thus, exclamations, baby talk, and onomatopoetic expressions are discussed separately, to observe whether there was any difference between them.

\subsection{Number of Concepts Used}

Altogether 96 concepts were expressed as exclamations, baby talk and onomatopes, collectively by the three boys during their observations. 
Table 2 - Boys' Use of Exclamations, Baby Talk and Onomatopes During Observations

\begin{tabular}{|c|c|c|c|c|c|c|c|}
\hline \multirow{3}{*}{ Subject } & \multirow{3}{*}{$\begin{array}{c}\text { Age at } \\
\text { observation }\end{array}$} & \multicolumn{6}{|c|}{ No \& $\%$ of semantic representations of concepts } \\
\hline & & \multicolumn{2}{|c|}{$\begin{array}{l}\text { Exclamations - } \\
\text { Total } 33\end{array}$} & \multirow{2}{*}{$\begin{array}{c}\text { Baby } \\
\text { talk - } \\
\text { Total } \\
6\end{array}$} & \multicolumn{2}{|c|}{$\begin{array}{l}\text { Onomatopes - } \\
\text { Total } 57\end{array}$} & \multirow[t]{2}{*}{$\begin{array}{c}\text { Total } \\
96\end{array}$} \\
\hline & & \begin{tabular}{|c} 
Estonian \\
- \\
Total 29
\end{tabular} & $\begin{array}{c}\text { English } \\
- \\
\text { Total } 13\end{array}$ & & $\begin{array}{c}\text { Estonian } \\
- \\
\text { Total } 57\end{array}$ & $\begin{array}{c}\text { English } \\
- \\
\text { Total } 9\end{array}$ & \\
\hline $\begin{array}{l}\text { Karl- } \\
\text { Oskar }\end{array}$ & $1 ; 11-3 ; 0$ & $\begin{array}{l}14=22 \% \\
(23)\end{array}$ & - & $\begin{array}{l}5=8 \% \\
(7)\end{array}$ & $\begin{array}{l}44=70 \% \\
(69)\end{array}$ & - & $63(99)$ \\
\hline Lembit & $1 ; 7-3 ; 0$ & $\begin{array}{l}15=44 \% \\
(25)\end{array}$ & $\begin{array}{l}5=15 \% \\
{[1]=3 \%} \\
(5)\end{array}$ & $\begin{array}{l}2=6 \% \\
(2)\end{array}$ & $\begin{array}{l}13=38 \% \\
(17)\end{array}$ & $\begin{array}{l}3=9 \% \\
{[3]=9 \%} \\
(5)\end{array}$ & $34(54) *$ \\
\hline Aksel & $2 ; 10-4 ; 0$ & $\begin{array}{l}19=44 \% \\
(41)\end{array}$ & $\begin{array}{l}8=19 \% \\
{[3]=7 \%} \\
(11)\end{array}$ & $\begin{array}{l}1=2 \% \\
(2)\end{array}$ & $\begin{array}{l}14=33 \% \\
(18)\end{array}$ & $\begin{array}{l}8=19 \% \\
{[6]=14 \%} \\
(12)\end{array}$ & $43(84) * *$ \\
\hline
\end{tabular}

Notes on Table 2: Input to Karl-Oskar was only in Estonian, to Lembit mainly in Estonian and to Aksel both in Estonian and English. Numbers in [ ] are for concepts expressed only in English; numbers in ( ) include the synonyms used. The last column of totals does not double-count the concepts expressed both in Estonian and English: $*=4$ concepts, $* *=7$ concepts.

Out of the 33 concepts that were produced as exclamations by the three boys, 29 occurred during speech in Estonian and far fewer (13) when Lembit and Aksel used English. The lower number of English concepts was not unexpected, as the boys were usually recorded when they were speaking in Estonian, and it is not taken as an indication of fewer English concepts being used altogether.

The number of concepts uttered by the two English-speaking boys as exclamations was fairly equal, being 15 and 19 in Estonian and five and eight in English. To enable meaningful comparison, the numbers have been converted in Table 2 to percentages of the total number of concepts used by each boy. This indicates that the boy in Estonia, Karl-Oskar, used far fewer exclamations (22\% of his total concepts) than the boys in Australia (Lembit 47\% and Aksel 51\%, together with the exclamations expressed only in English). 
Of the 13 exclamation concepts provided during English conversation by the boys in Australia, only four were expressed only in English, "whoopee" by Lembit and "boo", "ta da" and "wow", by Aksel, while the rest of English exclamations (nine) were expressed in Estonian as well, when the conversation was in that language, providing evidence of a developing bilinguality.

The boys produced collectively six expressions that are commonly used by adults when talking to children, so called baby talk. Of these five were used by KarlOskar: kalli-kalli (hugging), mammud (berries), tudub (sleeps), ata-ata (spanking), and tipa-tapa (walking). Lembit used only two baby talk terms: ata and karplauhti (falling). The only such term mentioned by the bilingually raised Aksel was tipatapa. Karl-Oskar's apparent superior usage of such terms may have been the result of his Estonian environment. Baby talk terms occurred in Estonian only.

Similar superiority was shown by Karl-Oskar in the expression of onomatope concepts, with his 44 onomatopes forming $70 \%$ of his total concepts. Both the boys in Australia were left far behind with their $47 \%$ of total his production.

Comparing the proportion of concepts expressed as exclamations to that of onomatopes, the results of the boy in Estonia, Karl-Oskar, are strikingly different from the two boys in Australia. While the proportions of Lembit and Aksel were very similar for both types of expressions (47\%-51\% of each boy's total concepts), Karl-Oskar's proportion of the exclamation concepts was less than half $(22 \%)$ of that of the other two and his onomatope concepts exceeded the others' by $23 \%$.

Why was his usage so radically different? Probably it was actually normal, and we should be asking instead why the proportions of exclamations were so high and of onomatopes so low in the speech of the boys in Australia.

The greater proportion of exclamation concepts of Lembit and Aksel may be partially explained by examining Table 3, which records the actual exclamations used by more than one boy, where especially Aksel's comparatively high number of synonymic expressions is obvious. It also appears that quite often he used the same exclamation in response to different stimuli or for different purposes, e.g., aah! both in recognition and in surprise or au/aauu also in surprise and upon mishap, etc. This may have been the result of the observer having made too fine a distinction between the intended motives, or the child being unsure in his choice of expression. It may be also that the Australian boys' actual exclamations as reactions to particular stimuli were issued more haphazardously, by whatever sound combination easily escaped, whereas Karl-Oskar kept more to the acquired terms.

Not only is the proportion of onomatope concepts considerably higher for the boy in Estonia than for the boys in Australia, but so are also his numbers of Estonian onomatope synonyms (Table 2). This could be taken as a clear indication of the benefit bestowed to Estonian vocabulary acquisition by growing up in an exclusively Estonian-using environment. 
Looking at the total number of 96 concepts expressed by the three boys as exclamations, baby talk and onomatopes, Karl-Oskar is in forefront with 63 concepts, followed by Aksel with 43 and Lembit with 34 concepts. The 10\% difference between Aksel and Lembit, both learning Estonian in Australia, is very interesting indeed. It seems to have come about mainly through the use of English, whereby Aksel's proportion of concepts expressed in English for both the exclamations and onomatopes was $19 \%$ of the total used, which was $4-10 \%$ more than Lembit's. Aksel's total advantage was not even upset by the proportion of his Estonian onomatope concepts being 5\% lower than Lembit's.

It seems to be an input issue, as Lembit did not have much exposure to English while both parents spoke to him in Estonian, including his mother who had learnt Estonian only recently as an adult. The deliberately bilingually raised Aksel, however, had a substantial English input from his father.

\subsection{Commonality of underlying concepts and their expressions}

The next question is whether the boys express the same concepts and whether they use the same terms for expressing their concepts. Tables 3,4 and 5 provide some indications of commonality.

Tables 3 and 5 show that out of the 33 exclamation concepts used, six Estonian exclamations were common to the three boys, two were common to Karl-Oskar and Lembit, three to Karl-Oskar and Aksel and two to Lembit and Aksel. Karl-Oskar produced three, Lembit five and Aksel eight individual Estonian exclamations.

There was a lot of variation in the exclamations used for particular intents (Table 3), both between the boys as well as for one boy. The high number of synonymous exclamations (52) of the deliberately bilingually raised Aksel was noted earlier, e.g., to express surprise he said during Estonian conversation $a u, a a h$, ähää!, o-o-o-o, oi, oo, ooh, ohoo! and uuh, and while speaking English he used "auu", "au", "uaah!" and "oh". The idea of haphazardous use of exclamations was reinforced by there being much less variation in expressing the same concept among onomatopes than the exclamations, both between the boys and also among the expressions by individual boys (comparing Tables 3 and 4). 
Table 3 - Exclamations used by more than one boy

\begin{tabular}{|c|c|c|c|}
\hline Intent & Karl-Oskar & Lembit & Aksel \\
\hline ballast expression & $m m h$ & $\begin{array}{l}a a ! \ddot{a} \ddot{a}, \text { aam-m, } \\
\ddot{a} \ddot{a} m, m-m\end{array}$ & $\begin{array}{l}a a, m-m ; \\
\text { aa (in English) }\end{array}$ \\
\hline in recognition & $\begin{array}{l}\text { aah! ah! äh, } \\
\text { äähh }\end{array}$ & $a h !$ & $\begin{array}{l}\text { aah! äh-äh! ääh! ai; } \\
\text { aah (in English) }\end{array}$ \\
\hline experiencing pain & $\begin{array}{l}a i ! a i a, a i h ! a i- \\
a i-a i-a i-a i, a i-a i\end{array}$ & aаu, ä̈̈u & $a i-a i, a i, a a i$ \\
\hline in surprise & oih! & $o h, a h, u h, u u h$ & $\begin{array}{l}\text { au,aah,ähää! o-o-o-o, } \\
\text { oi, oo, ooh, ohoo! uuh; } \\
\text { auu,au, uaah! oh (in } \\
\text { English) }\end{array}$ \\
\hline sighing & oë̈̈̈, õ̃hh & $\ddot{a} h$ & $\tilde{o h}$ \\
\hline $\begin{array}{l}\text { affirmation (in } \\
\text { addition to jah/jaa) }\end{array}$ & $m h-m h$ & $\begin{array}{l}m-m, m h-m h ; \\
\text { sure (in } \\
\text { English) }\end{array}$ & $m-m, m h-m h$ \\
\hline $\begin{array}{l}\text { answering } \\
\text { telephone/phone }\end{array}$ & ollo-ollo, allo & $\begin{array}{l}\text { allo; hellou (in } \\
\text { English) }\end{array}$ & \\
\hline grunt & $m h !$ & $m h !$ & \\
\hline help! & appi! & & appi! \\
\hline laughing & $\ddot{a} h-\ddot{a} h !$ & & 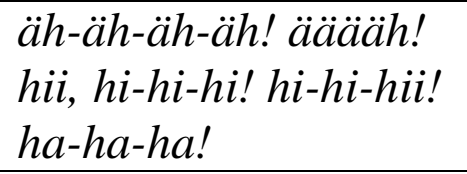 \\
\hline singing & taa-baa & & $\begin{array}{l}\text { tüttüdü-tüü, lal-lala- } \\
\text { laa }\end{array}$ \\
\hline thanks! & & aitäh! & täh*! (aitäh) \\
\hline upon mishap & & auu! & aauu!;auu (in English) \\
\hline $\begin{array}{l}\text { Total number of } \\
\text { shared } \\
\text { exclamations }\end{array}$ & $11(20)$ & $10(21)$ & $11(39)$ \\
\hline
\end{tabular}

(Total numbers in brackets include synonyms)

Table 4 provides the actual onomatopoetic expressions used by more than one boy, and Table 5 indicates their numerical data related to commonality. 
Table 4 - Onomatopes used by more than one boy

\begin{tabular}{|c|c|c|c|}
\hline Concept & Karl-Oskar & Lembit & Aksel \\
\hline barking & auh & $\begin{array}{l}\text { vuff-vuff-vuff } \\
\text { (Eng) }\end{array}$ & woof ( Eng) \\
\hline doorbell chiming & till-till, till-tõll & $\begin{array}{l}\text { ding-dong, din- } \\
\text { gong, dingon } \\
\text { (Eng) }\end{array}$ & ding-dong (Eng) \\
\hline banging & põmm-pimm & bõm, bam & \\
\hline $\begin{array}{l}\text { alarm clock } \\
\text { ringing }\end{array}$ & kill-kôll & kõll & \\
\hline taking on lap & opa, anna opa & up-pa, ираa & \\
\hline swishing sound & p-p phh-hh & phh & \\
\hline motor sound & $\begin{array}{l}\text { pu-u-u, } \\
\text { põlpõ } l^{*}(p \tilde{o r r-p o r r r})\end{array}$ & uu & \\
\hline ticking/clock & tik-tak, tak-tak & tic-toc (Eng) & \\
\hline train /train sound & tuh-tuh & tsuhh & \\
\hline pain/painful/hurts & $\begin{array}{l}a i-a i-a i, a i, a i-a i a, a i- \\
a i\end{array}$ & & aaii \\
\hline blowing & puhh,puh & & f-f-f-f (Eng) \\
\hline knocking & $\begin{array}{l}\text { kop-kop, kop-kop- } \\
\text { kop }\end{array}$ & & $\begin{array}{l}\text { kop-kop (Est), } \\
\text { täp-täp (Eng) }\end{array}$ \\
\hline tickle & tik-tok & & $\begin{array}{l}\text { kõdi-kõdi(Est), ta- } \\
\text { ta-ta-taa, ta-tiko- } \\
\text { tiko,tiki-tiki (Eng) }\end{array}$ \\
\hline eating/food/tasty & $\begin{array}{l}\text { mäm-mämm, } \\
\text { nämmi-nämmi }\end{array}$ & & $m-m, a m m$ \\
\hline landing sound & $\begin{array}{l}\text { opsi*(popsti), } \\
\text { potsti, opsti }\end{array}$ & & paauu! (Eng) \\
\hline beeping & piip-piip & & piip \\
\hline drilling & prrr & & prrr, purr \\
\hline $\begin{array}{l}\text { drum/drum } \\
\text { sound }\end{array}$ & trumm-trumm & & $\begin{array}{l}\text { rat-tat-taa, lat-tat- } \\
\text { taa (Eng) }\end{array}$ \\
\hline baby sounds & $\begin{array}{l}\text { te-pe-pe-pea-pe- } \\
\text { pe-pe,pä-pä-pä-pä }\end{array}$ & & $\ddot{O}-\ddot{O}-\ddot{O}-\ddot{O}$ \\
\hline tooting & tuut-tuut & & toot, toot-too (Eng) \\
\hline clap & & plaks & plaks \\
\hline Total No shared & $20(30)$ & $10(14)$ & $14(18)$ \\
\hline
\end{tabular}

(Total numbers in brackets include synonyms) 
Table 5 - Commonality - Number of Concepts Used by the Boys

\begin{tabular}{|c|c|c|c|c|c|c|c|c|}
\hline & \multicolumn{8}{|c|}{ No of concepts } \\
\hline $\begin{array}{l}\text { Type of expression } \\
\text { Total number }\end{array}$ & \multicolumn{2}{|c|}{$\begin{array}{c}\text { Exclamations } \\
33\end{array}$} & \multicolumn{2}{|c|}{$\begin{array}{c}\text { Baby talk } \\
6\end{array}$} & \multicolumn{2}{|c|}{$\begin{array}{c}\text { Onomatopes } \\
57\end{array}$} & \multicolumn{2}{|c|}{$\begin{array}{c}\text { Total } \\
96\end{array}$} \\
\hline Language & Est & Eng & Est & Eng & $\begin{array}{c}\text { Est } \\
\mathrm{A} / \mathrm{L} \quad \mathrm{KO}\end{array}$ & Eng & Est & Eng \\
\hline $\begin{array}{l}\text { Karl-Oskar, Lembit } \\
\& \text { Aksel }\end{array}$ & 6 & $\begin{array}{l}3 \mathrm{~A}[0] \\
1 \mathrm{~L}[0]\end{array}$ & & & & $\begin{array}{c}2 \mathrm{~A}+2 \mathrm{~L} \\
{[2]}\end{array}$ & 8 & $6[2]$ \\
\hline Karl-Oskar \& Lembit & 2 & $1 \mathrm{~L}[0]$ & 1 & & 6 & $1 \mathrm{~L}[1]$ & 10 & $2[1]$ \\
\hline Karl-Oskar \& Aksel & 3 & & 1 & & $\begin{array}{ll}7 & 11\end{array}$ & $6 \mathrm{~A}[4]$ & 15 & $6[4]$ \\
\hline Lembit \& Aksel & 2 & $1 \mathrm{~A}[0]$ & & & 1 & & 3 & $1[0]$ \\
\hline Karl-Oskar only & 3 & & 3 & & 24 & & 30 & \\
\hline Lembit only & 5 & $3[1]$ & 1 & & 6 & & 12 & $3[1]$ \\
\hline Aksel only & 8 & $4[3]$ & & & 6 & & 14 & $4[3]$ \\
\hline Total Nos & 29 & $13[4]$ & 6 & 0 & $50 \quad 57$ & 9 9[7] & 92 & $22[11]$ \\
\hline
\end{tabular}

$\mathrm{A}=\mathrm{Aksel}, \mathrm{L}=$ Lembit, Concepts expressed only in English are in brackets [ ]

The largest number of concepts expressed in common as onomatopes were produced by Karl-Oskar and Aksel. For these eleven Estonian concepts of KarlOskar, Aksel used seven Estonian and six English onomatopes (two concepts (knocking and tickling) were expressed in both languages - see Table 4). Karl-Oskar and Lembit had seven concepts in common (for one of which Lembit used just the English term "tic-toc" without the Estonian equivalent), whereas Lembit and Aksel shared only one concept (clapping, expressed with the same term plaks), and the three boys had only two concepts in common (for barking and the doorbell). The latter two concepts were expressed by both boys in Australia in English.

Leaving aside baby talk and Karl-Oskar's expressions, as none of these were in English, it is interesting to note that out of the total 63 concepts expressed as exclamations and onomatopes by the two boys in Australia, 22 were in English, of which half were just in English alone, while the remaining half had also Estonian equivalents. Thus the proportion of concepts expressed in English was 35\% of total and those used in both languages was $17 \%$. This provides evidence of a reasonable degree of bilinguality in the Australian boys' use of exclamations and onomatopes.

The proportion of a boy's words used in common with the other boys during their observation periods out of the total used by the three boys has been named 
earlier as his commonality index (Salasoo 2005). This measure, applied to different word types, provides a useful means of comparison, shown in Table 6.

Table 6 - Commonality indices - \% of Concepts Used in Common with Another Boy (including English concepts)

\begin{tabular}{|l|c|c|c|c|c|c|c|}
\hline Total No concepts & \multicolumn{2}{|c|}{ Exclamations 33 } & \multicolumn{2}{c|}{ Baby talk 6 } & \multicolumn{2}{c|}{ Onomatopes 57 } & \multirow{2}{*}{ Total 96 } \\
\cline { 1 - 7 } Commonality of & $\begin{array}{c}\text { own } \\
\text { total }\end{array}$ & $\begin{array}{c}3 \text { boys' } \\
\text { total }\end{array}$ & $\begin{array}{c}\text { own } \\
\text { total }\end{array}$ & $\begin{array}{c}3 \text { boys' } \\
\text { total }\end{array}$ & $\begin{array}{c}\text { own } \\
\text { total }\end{array}$ & $\begin{array}{c}3 \text { boys' } \\
\text { total }\end{array}$ & \\
\hline Karl-Oskar & $79 \%$ & $33 \%$ & $40 \%$ & $33 \%$ & $45 \%$ & $35 \%$ & $33 \%$ \\
\hline Lembit & $63 \%$ & $30 \%$ & $50 \%$ & $17 \%$ & $63 \%$ & $18 \%$ & $20 \%$ \\
\hline Aksel & $50 \%$ & $33 \%$ & $100 \%$ & $17 \%$ & $70 \%$ & $25 \%$ & $27 \%$ \\
\hline
\end{tabular}

It seems that commonality of the concepts used for the exclamations was very similar among the boys (30-33\% of the total 33 concepts used), whereas for the 57 onomatope concepts used by the boys, commonality varied greatly, being most for Karl-Oskar (35\%), 25\% for Aksel, and only $18 \%$ for Lembit. Although the small number of baby talk concepts used renders their percentages almost meaningless, they have been included in the total of 96 , for which the commonality indexes of the boys still greatly differ, influenced by the disparity among the onomatopes.

Karl-Oskar in Estonia had the highest fairly consistent commonality index with the other boys for all the types of expressions examined, ranging from $33 \%$ to $35 \%$. While Lembit, in Australia, had a very similar commonality index with the other boys for the exclamations (30\%), his commonality with the other boys for the onomatopes and baby talk was half of that of Karl-Oskar (18\% and 17\%, respectively). The contrast between the onomatope commonality of the bilingual Aksel in Australia and Karl-Oskar in Estonia was not so pronounced (25\% and 35\%, respectively).

Table 6 reveals a further curious difference between the use of exclamations and onomatopes. Whereas $79 \%$ of Karl-Oskar's exclamations were used also by the other boys, only $45 \%$ of his onomatopes were. Yet for Lembit the percentage used by others was the same (63\%) for both types of concepts and for Aksel it was opposite to Karl-Oskar (50\% of exclamations and $70 \%$ of onomatopes). This seems to have been influenced by the large number of onomatope concepts (44) used by Karl-Oskar during the observations, reflecting again his obviously richer input.

Assuming that Karl-Oskar's speech represented a typical Estonian boy's vocabulary, the onomatopoetic concepts of the boys in Australia were compared with his. Calculating from Table 5 reveals that 18 (29\%) of Karl-Oskar's 63 Estonian concepts for exclamations, onomatopes and baby talk, collectively, were also used 
by Lembit and 23 (37\%) were used by Aksel. Such a dissimilarity between the two boys' concept numbers, however, disappears if one considers their proportion of each boy's total concepts: altogether Aksel expressed 43 against Lembit's 34 concepts (Table 2), for which their commonality with Karl-Oskar was almost the same $(18 / 34=52.9 \%$ and $23 / 43=53.4 \%)$. This indicates that over half of the concepts of each of the boys in Australia was also expressed by the boy in Estonia, i.e., they were learning the same language, at least as far as the examined expressions were concerned.

\subsection{Classification of the boys' onomatopoetic expressions}

The onomatopes used by the observed children may be classified either according to the source of inspiration for forming a word that indicates a meaning associated with the source, e.g., a car being indicated by the sound it makes, "prr-rr", or by the onomatopoetic sounds themselves. Veldi (1987, 2013) has grouped Estonian onomatopes according to phonological principles, applying Voronin's classification, based on the typology of extralinguistic sounds, to the onomatopoetic expressions in the Estonian language. In Figure 1, however, the initially mentioned, semantic approach is taken, i.e., ending with what the child is trying to express with the uttered sounds imitating the inspiring source.

The sources have been initially divided broadly into sounds made by inanimate and animate subjects, and the inanimate subjects into sounds made by mechanical objects. These in turn were divided into sounds coming from vehicular objects, e.g., tsuhh-tsuhh coming from a train, and other mechanical sounds, e.g., "ding-dong" from a doorbell.

Animate sounds were divided into animal sounds and sounds indicating some action. It was often hard to distinguish whether animal sounds meant the sound made by the animal, e.g., teeb ki-ki-lii-lii (crows) or the rooster itself ki-ki-lii-lii. KarlOskar's sounds imitating galloping meant both the horse and its actions. Some onomatopes, however, meant unmistakably just the animal, e.g., the call issued to chickens tibi-tibi was used to indicate the chick itself.

Many sounds were used to express some animate action, e.g., näm-näm and its numerous synonyms for eating, krõmps- krõmps for crunching, etc.

Whereas out of the total concepts of the boys expressed by onomatopoetic means about a quarter to a third were in common, Tables 3 and 4, and also Figure 1 demonstrate that the expressions of particular concepts were not always uniform, but varied between the boys, as well as varying over time within the vocabulary of a particular boy -- e.g., Karl-Oskar exclaimed upon surprise oih! 
Figure 1 - Sources of Estonian Onomatopoetic Expressions of Three Small Boys

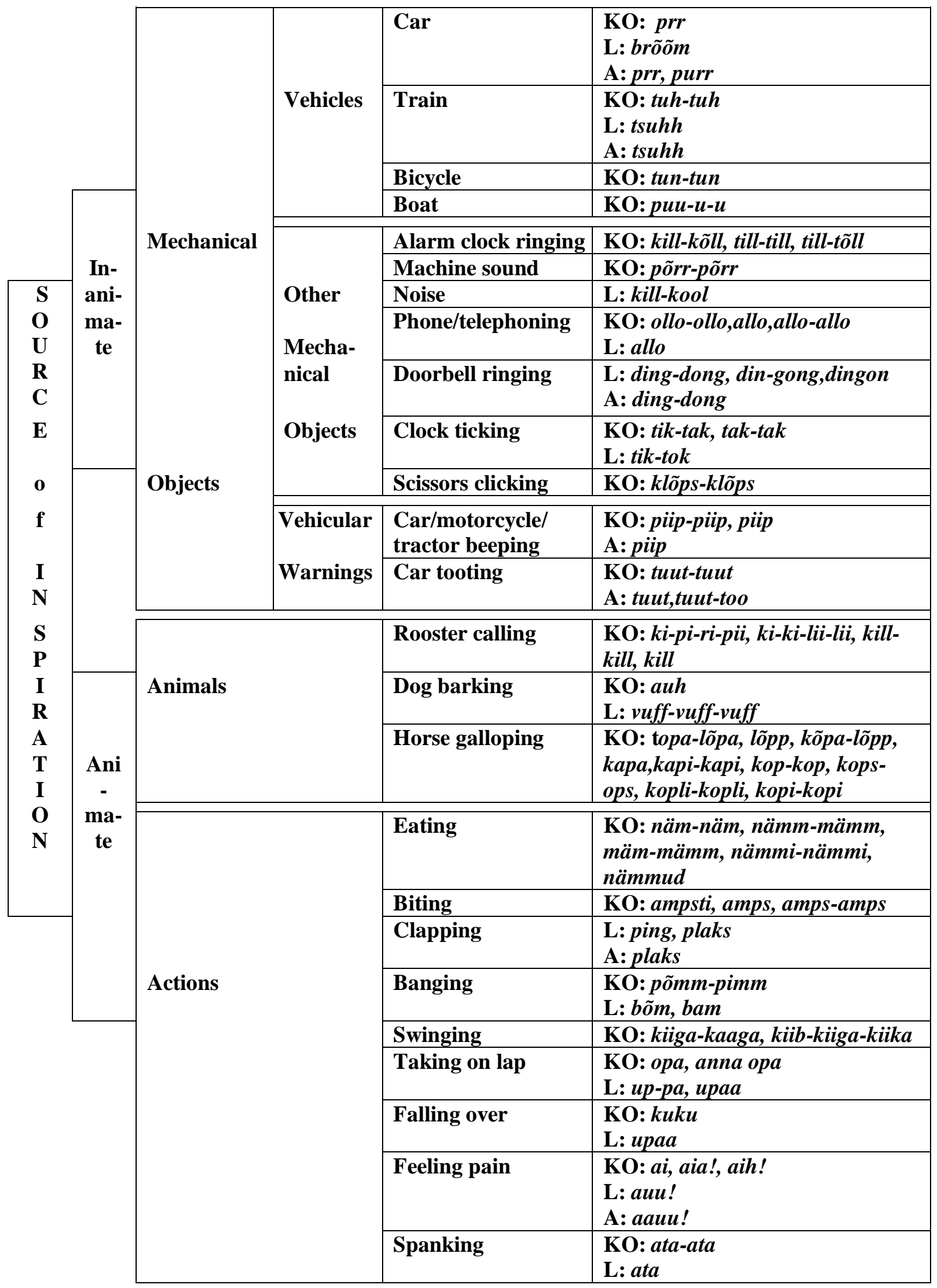


Lembit called out $o h$, ah, uh and uuh! and Aksel used in Estonian conversation au,aah, ähää!, o-o-o-o, oi, oo, ooh, ohoo! uuh and when speaking English "auu", "au", "uaah!" and "oh". Karl-Oskar, in the most favourable learning situation, used for years numerous onomatopoetic synonyms interchangeably to indicate a horse and galloping, before eventually arriving via mispronunciation at the standard term for horse hobune when he was over four years of age. Most standard language terms for the onomatopes used appeared earlier than that in the boys' vocabulary, and gradually began to be used more and more.

\section{Conclusions}

The current study of occurrence of onomatopoeia in the initial speech of three small children acquiring Estonian in different environments has revealed that all the studied children were using onomatopoetic terms in Estonian, while the boys living in Australia were also using some English terms. For half of the onomatopoetic expressions in English, their Estonian counterparts were used as well, thereby providing evidence of a certain bilinguality.

There were two main differences in the use of onomatopoetic expressions between the boys acquiring Estonian in Australia and the boy in Estonia. As parents usually tend to use baby talk and onomatopoetic terms with young children, it is expected that the children's input would be rich in such terms, but in this investigation the Estonian input of the two boys in Australia was probably limited in this respect. This is reflected, when compared to the boy in Estonia, in their much lower percentage of concepts expressed in baby talk and onomatopes.

In contrast, the proportion of exclamations of their total onomatopoetically expressed concepts was twice as high and much more varied for the boys in Australia than for the boy in Estonia. This seems to indicate a haphazard, rather than acquired production of some exclamations.

However, as over half of the onomatopoetically expressed concepts of each of the boys in Australia were also used by the boy in Estonia, it seems all the boys were learning the same language, at least as far as the examined expressions were concerned. Moreover, the early appearance of audibly identifiable onomatopoetic terms and their prevalence in the young children's Estonian speech seems to point to a relatively easy acquisition of onomatopes at the early stage of language development.

The onomatopes used by the boys have been classified according to the inspiring source for forming a word that indicates a meaning associated with the source. 


\section{References}

Assaneo, María Florencia, Juan Ignacio Nichols, and Marcos Alberto Trevisan. (2011) The Anatomy of Onomatopoeia. PLoS ONE 6(12), e28317.

Retrieved from doi:10.1371/journal.pone. 0028317.

Chiarantano, Stefan. (2006) Onomatopoeia.

Retrieved from www.tefl.net/esl-articles/onomatopoeia.htm.

Kuiper, Koenraad. (2000) On the Linguistic Properties of Formulaic Speech. Oral Tradition 15/2, pp. 279-305.

Rätsep, Huno. (1983) Eesti kirjakeele tüvevara päritolu. Keel ja Kirjandus 10, pp. 539-548.

Salasoo, Tiiu. (1996) Observations in the natural acquisition of Estonian morphology - a mix-and-match of stems and suffixes. In Maisa Martin and Pirkko Muikku-Werner (eds.), Finnish and Estonian - New Target Languages (pp. 86-115). Jyväskylä: University of Jyväskylä Centre for Applied Language Studies.

Salasoo, Tiiu. (1998a). Same goal in three settings: early acquisition of Estonian in native monolingual, non-native monolingual and bilingual environments. Paper presented at the XVI International Congress of Linguistics at Paris, France, 2025.7.1997. Elsevier CD-ROM on the conference, 147, so7, 24. Retrieved from asiainfo@elsevier.com.sg or nlinfo-f@elsevier.com.

Salasoo, Tiiu. (1998b) Esimene isik Austraalia kakskeelse lapse arenevas keeles [The First Person in the Language of a Bilingual Child in Australia]. In Liina Lindström (ed.), Väliseestlaste keelest [About the Language of Estonians Abroad], Tartu ülikooli eesti keele õppetooli toimetised 9 (pp. 81-100). Tartu: University of Tartu.

Salasoo, Tiiu. (2001) How do Children Manage to Learn Estonian? Initial Acquisition. In Tõnu Seilenthal, Anu Nurk, and Triinu Palo (eds.), Congressus nonus internationalis Fenno-Ugristarum, Tartu 7.-13.8.2000: Pars 4, Dissertationes sectionum: Linguistica 1 (pp. 122-132). Tartu : Congressus 2001.

Salasoo, Tiiu. (2002a) Use of Initial Estonian and English Verb Forms by a Bilingual Child. In Liina Lindström and Oksana Palikova (eds.), Emakeel ja teised keeled III [Mother Tongue and Other Languages III], (pp. 181-206). Tartu: University of Tartu.

Salasoo, Tiiu. (2002b) What actions do children learning Estonian talk about? In Zita McRobbie-Utasi and Connie K. So (eds.), Proceedings of the XIII Conference of the Finno-Ugric Studies Association of Canada (pp. 45-60). Burnaby, BC: Simon Fraser University. 
Salasoo, Tiiu. (2003) The early nouns - What do children learning Estonian talk about? Paper presented at XVII International Congress of Linguists in Prague, July 24-29, 2003. In E. Hajicova, A. Kotesovcova, and J. Mirovsky (eds.), Proceedings of CIL17, CD-ROM. Prague: Matfyzpress, MFF UK.

Salasoo, Tiiu. (2005) The initial vocabulary of children learning Estonian - What do they talk about? In I.G. Ivanov (ed.), Congressus Decimus Internationalis Fenno-Ugristarum, Yoshkar-Ola, 15.08-21.08.2005: Pars 2, Summaria acroasium in sectionibus: linguistica (pp. 225-227). Yoshkar-Ola: Mariı̌skiı̌ gos. universitet.

Salasoo, Tiiu. (2010a) Laste esimesed eestikeelsed omadussõnad. Eesti ja soomeugri keeleteaduse ajakiri 1/Journal of Estonian and Finno-Ugric Linguistics 1, pp. 57-80.

Salasoo, Tiiu. (2010b) Estonian boys learning how to elaborate with adverbs. Paper presented at the Seventeenth Conference of the Finno-Ugric Studies Association of Canada, at Concordia University, Montreal, May 29-31, 2010.

Tsoi, Wai Chuen Thomas and Chung Hoi Wai Clara. (2004) Characteristics of Onomatopoeia, Term paper, LIN1001 Discovering Linguistics, The Chinese University of Hong Kong. Retrieved from www.thomastsoi.com/wpcontent/downloads/Characteristics\%20of\%20Onomatopoeia.pdf.

Veldi, Enn. (1987) Estonian Onomatopoeia: A Typological Approach. Proceedings of the XI International Congress of Phonetic Sciences (pp. 193-196). Tallinn, Estonia: Eesti NSV Teaduste Akadeemia

Veldi, Enn. (2013) Estonian onomatopoeia: a typological approach. Paper presented at the International Conference of Applied Linguistics: Languages and People: Space, Time, Identity at Vilnius University, October 3-4, 2013. 